\title{
Information Systems Inventory of Goods in The Warehouse at PT. Transvision
}

\author{
Khaidir Zulkhaida * \\ Institute of Information Technology, AMIK Indonesia \\ Email: khaidirzulkhaida@ amikindonesia.ac.id \\ Yunan Henryanto \\ Research Division, Jhonson Coorporation \\ Email: yunanhenryanto@jhonsoninternational.com
}

\author{
Hasan Jaenuddin \\ Research Division, PT. Epsilon \\ Email: hasan.jaenuddin@epsilon.co,id
}

Received: 12 January 2021; Accepted: 16 March 2021; Published: 1 April 2021

\begin{abstract}
On the other hand, the system currently running at PT. Transvision, especially in the inventory section, in data processing errors often occur delays in goods orders due to monitoring of stock items that are still done manually with the number of items available. Even if the goods that consumers are looking for are in empty stock because the delay in stock input of goods can cause sales to decline, the goods that should be able to be sold cannot be sold. The author makes a problem limitation only on the Inventory Information System at PT. Transvision Banda Aceh using Visual BASIC.NET application, which is the purpose of writing, namely to identify and design the Inventory Information System at PT. Transvision Banda Aceh. There are two methods that the author uses to collect data, namely field studies and library studies. From the results of research and observations that have been made at PT. Transvision Banda Aceh, it can be concluded that the existence of this Inventory Information System Program Information system at PT. Transvision Banda Aceh becomes precise, and accurate, especially in the inventory section. And obtain information about the inventory of these goods becomes easier and this information system is able to solve problems that often occur at PT. Transvision Banda Aceh is difficult in controlling and supervising the inventory of goods and planning the procurement of goods. This procurement information system can avoid excess inventory and overcome the scarcity of goods which is of course highly expected by business actors so that an information system program is created in order to obtain quality information.
\end{abstract}

Index Terms: Information Systems; Inventory, Goods; Visual BASIC.NET.

\section{Introduction}

Along with the development of information technology in the community, it is increasingly familiar with the use of computer-based programs that function to support the performance of a company so that it can run according to the desired target [1]. One example of the use of information technology in the computer sector is the use of information system programs in the form of process input and output as well as detailed reports on the input of the program [2]. The definition of the information system program itself is a form of supporting means to recap data and can display a form of a report from the data recap complete with the date and time at the time of inputting the data $[2,3]$.

In a company, if you have used this method, it will help the process of company performance that has been carried out. It is enough to use a PC (Personal Computer) and original software and use the information system program itself [4, 5, 6]. For companies established by a government or private party such as PT. Transvision Banda Aceh which is engaged in Telecommunication and Media Infrastructure in Indonesia, such as pay television and others, the rate of increase or decrease in sales greatly affects the quality of the company itself. To fulfill the need for fast, precise, and accurate information in data processing, we need a system capable of providing facilities and complete facilities as a service to the users and users of the system itself.

On the other hand, the system currently running at PT. Transvision Banda Aceh, especially in the inventory section, in data processing errors often occur, delays in goods orders due to monitoring of stock items that are still done manually with the number of items available. Even if the goods that consumers are looking for are in empty stock because the delay in the input of the goods' stock can cause sales to decline, the goods that should be able to be sold cannot be sold [7, 8]. 
The thing that becomes an obstacle at PT. Transvision Banda Aceh is a data collection on the inventory of goods and the input of sales transactions is still done manually. So that there are often errors in recording the reports to be made. a research objective is to determine and design the Inventory Information System at PT. Transvision Banda Aceh.

\section{Background and Analysis}

An inventory information system is a system that discusses the inventory section, especially inventory reports, incoming goods reports, goods purchase reports, goods returns reports, and goods delivery reports. System analysis is the initial stage before the design stage, this is done to identify problems and deficiencies of the existing system. The data that is managed on the current system is not systematic, where the data that is owned cannot describe the data uniquely. Seeing the condition of the data processed by the current system, it is necessary to create a data coding system, so that some data of the same type can be recognized as the desired object.

In the process of processing inventory data at PT. Transvision Banda Aceh has used a computerized system using standard applications such as Microsoft Office Excel, but problems also often occur due to repeated data filling in determining data storage per day so that the process seems slow. And the process of making reports sometimes goes wrong and sometimes experiences delays in delivery to the parties concerned. Besides that, it also causes a waste of time and energy. There are still many shortcomings in the data creation process, namely:

a) The time needed is too long, starting from the process of entering the inventory information data from the parts to making the inventory report

b) Arrangement of inventory is sometimes done using the Excel application, which makes it difficult to find files within a certain time

c) Insufficient data security because the storage media used is easily damaged and easily accessible by many people.

The procedures for the ongoing inventory system are as follows:

a) The warehouse department makes a report on the inventory of goods based on the amount of stock remaining Inventory reports are made in two copies, the first copy is given to the owner, while the second copy is filed by the warehouse department.

b) The inventory report is used for raw materials as a letter of request for goods, before being submitted to the supplier, the letter must be signed by the owner.

c) After the supplier sends the goods and the purchase invoice. The warehouse department will make a match first after making the incoming goods report.

d) Reports on incoming goods are made in duplicate, the first copy is submitted to the owner, while the second copy is filed in the warehouse section.

e) The inventory section makes goods returns in 2, the first copy is filed and the second copy is submitted to the supplier along with the goods.

f) The inventory department makes a letter of delivery of goods for counters and counters to provide reports of goods and goods returns to the inventory department.

\section{Result Analysis and Discussion}

System design is the activity of developing procedures and processes that are currently running to produce a new system or updating existing systems to increase work effectiveness in order to meet the results used with the aim of utilizing available technology and facilities. In this chapter, the author will provide a suggestion which is a computerized information system that is expected to help and simplify the work.

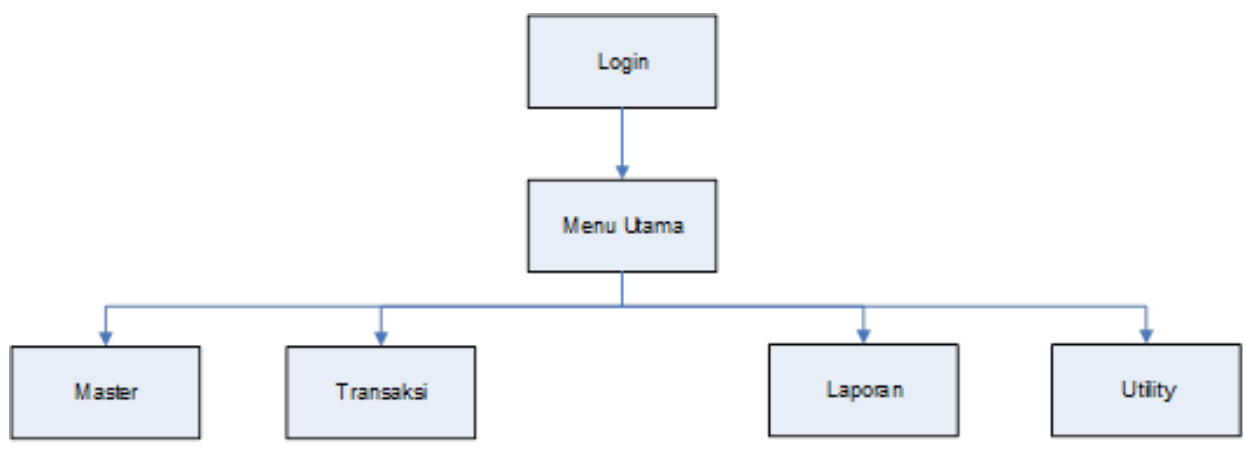

Fig.1. Program Menu Structure 
Relationships are relationships between tables that represent relationships between objects in the real world [9, 10]. Relationships are relationships that occur in a table with others that represent relationships between objects in the real world and function to regulate the operation of a database $[11,12,13]$. The Relationship Between the Tables is shown in Figure 2 below.

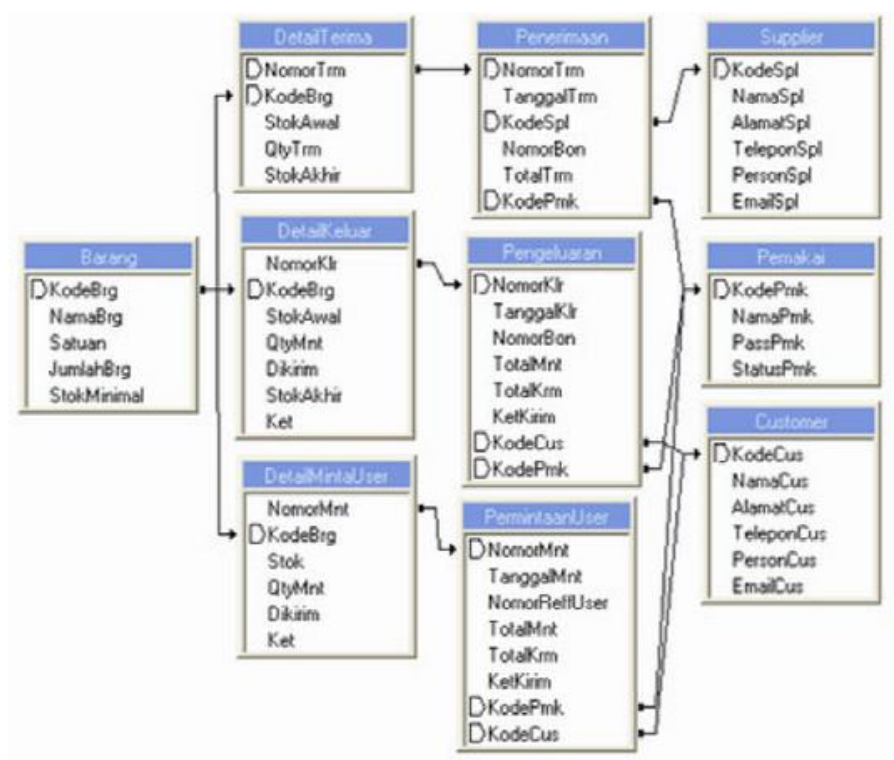

Fig.2. Relations Databases

The results of this study produce an employee data collection application as shown in Figure 6 below .

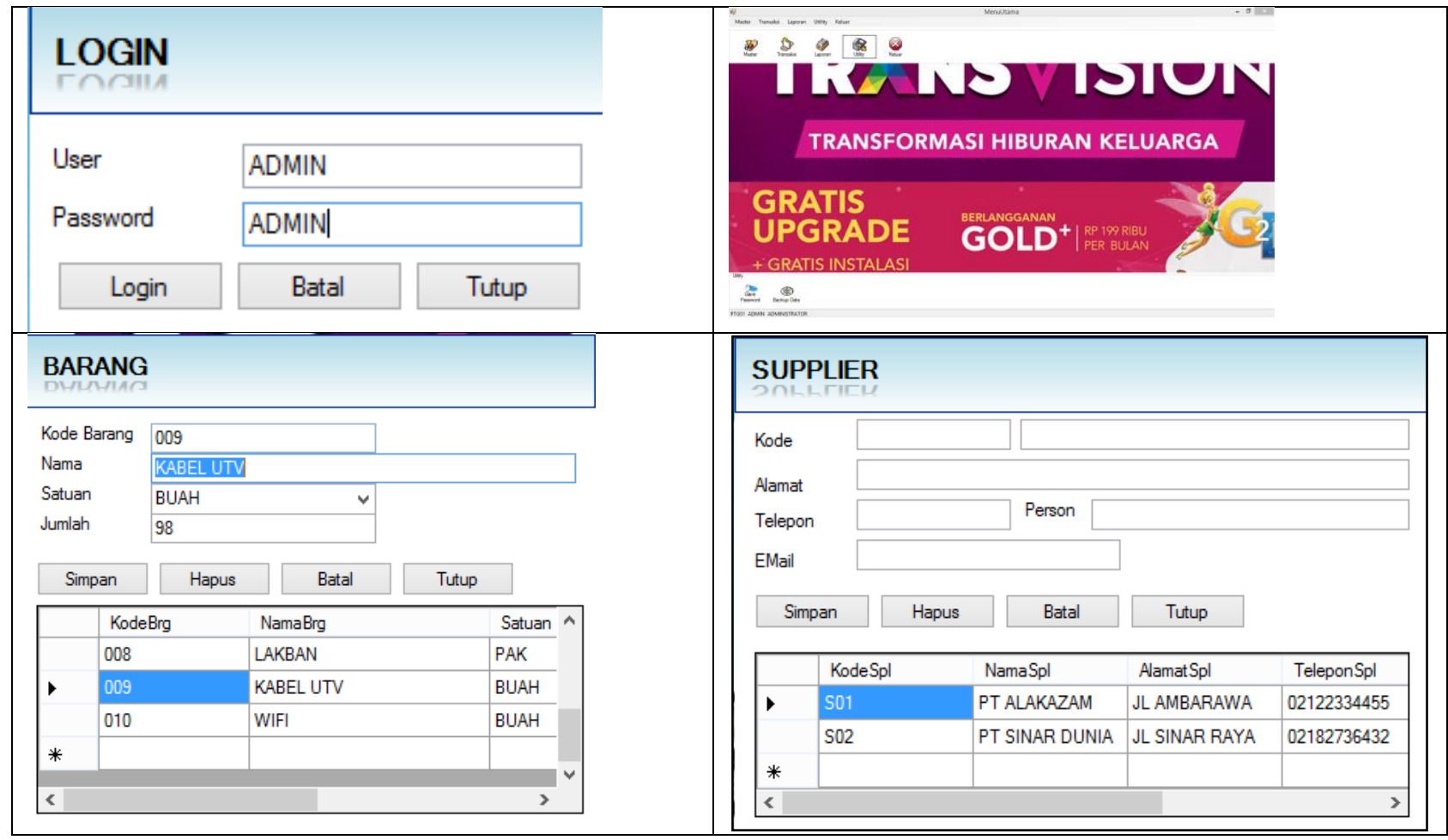




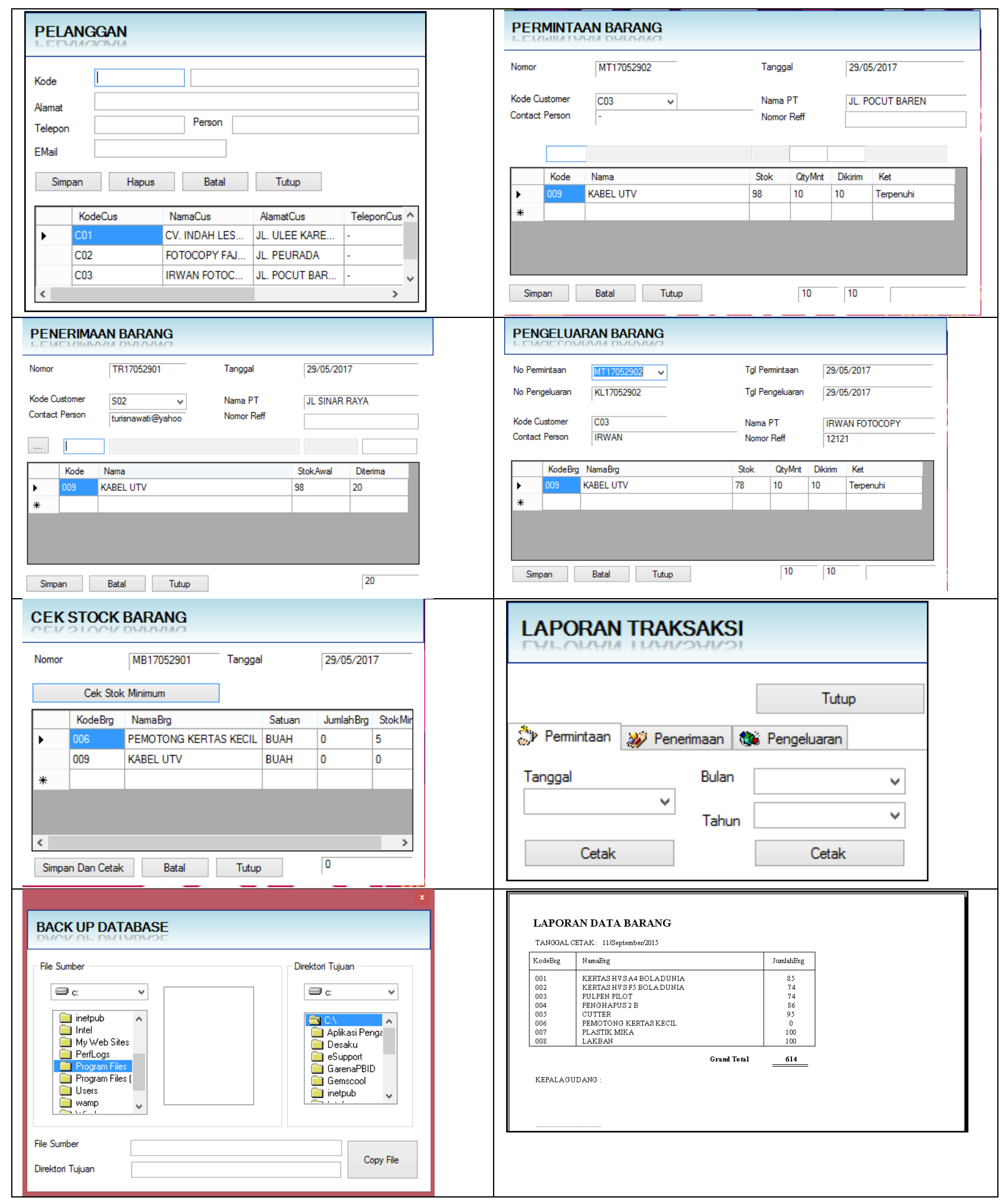

Fig.3. Application Results

This research produces an inventory application starting from the login form, filling in the user, registering goods, suppliers, customers, goods issuance form, incoming goods form, checking inventory, to reporting inventory as shown in Figure 3. The following is hardware and software required to use the inventory system program, viz:

a. Hardware

Hardware that can support this application requires hardware with specifications:

1. Minimum Pentium 3 CPU with a speed of $633 \mathrm{Mhz}$

2. $256 \mathrm{MB}$ ram 


\author{
3. Minimum 1 GigaByte hard disk \\ 4. Monitor \\ 5. Keyboard and Mouse \\ 6. Printer
}

b. Software

Software that supports this application includes:

1. Windows 7,8,10, Linux, Symbian, Android

2. NET Framework 4.0 or above

3. Xampp.

\title{
4. Related Work
}

Previous research conducted by Junaidi, Agus, and Candra Sumirat (2018) developed a Goods Inventory Application for PT. Solusindo CAD Using the Waterfall Method. In the process of recording and calculations performed by PT CAD Solusindo until today still use the Microsoft Excel program, starting from the receipt of goods, goods out and preparing reports addressed to the leader. Designing the system described by UML modeling. The programming language used is PHP and MYSQL database. It is expected that these applications can help the PT. CAD Solusindo to help users further improve supervision of the stocks held in the company so that the quality of reports implies more accurately, quickly, and precisely when required as annual audits [14]. Taufiq Iqbal, Daniel Aprizal, and Muhammad Wali (2017) conducted research and built an inventory application by applying the EOQ (Economic Order Quantity) method as a basis for development. This research method is divided into three stages, namely pre-development data collection, development and implementation, and post-development data collection. The results of this study are an inventory application using the EOQ Probabilistic method which emphasizes the results in a graphical form to make it easier for company owners to make decisions $[8,9]$. It can be seen that several other studies have conducted and developed applications and methods related to inventory by promoting better stock management optimization $[15,16,17]$.

\section{Conclusion}

From the results of research and observations that have been made at PT. Transvision Banda Aceh, the following conclusions can be drawn:

a) With the Inventory Information System Program this information system at PT. Transvision Banda Aceh becomes precise, and accurate, especially in the inventory section. And to obtain information about the inventory of these goods becomes easier.

b) This information system is able to solve problems that often occur at PT. Transvision Banda Aceh is difficult in controlling and supervising the inventory of goods and planning the procurement of goods. This procurement information system can avoid excess inventory and overcome the scarcity of goods, which is of course highly expected by business actors.

c) The creation of an information system program in order to obtain quality information.

\section{References}

[1] Amri, Khairul. "Persepsi mahasiswa terhadap kualitas layanan Pendidikan Akademi Manajemen Informatika dan Komputer Indonesia (AMIKI) Banda Aceh." Jurnal Ekonomi Manajemen dan Bisnis 1.1 (2013): 118-139.

[2] Ahmad, Lukman. Sistem Informasi Manajemen: Buku Referensi: Sistem Informasi Manajemen. Vol. 1. KITA Publisher, 2018.

[3] Syafwandhinata, Jhony, and Lukman Ahmad. "Sistem Pemasaran Jasa Freelancer IT (Studi Kasus: AMIK Indonesia)." Jurnal JTIK (Jurnal Teknologi Informasi dan Komunikasi) 3.1 (2019): 1-6.

[4] Wali, Muhammad, and Lukman Ahmad. "Source Code Library (SCL): Application Support Learning Software Development: Source Code Library (SCL): Application Support Learning Software Development." Jurnal Mantik 4.1 (2020): 7-13.

[5] Wali, Muhammad, and Safrizal Safrizal. "Similar text sebagai Pengkodean Aplikasi Plagiarisme." Jurnal JTIK (Jurnal Teknologi Informasi dan Komunikasi) 2.1 (2018): 11-19.

[6] Bahruni, Bahruni, and Fathurrahmad Fathurrahmad. "Analisis Trend Topik Pengembangan Rekayasa Perangkat Lunak dalam mendukung Strategi Kurikulum Perguruan Tinggi." Jurnal JTIK (Jurnal Teknologi Informasi dan Komunikasi) 3.2 (2019): 7074. 
[7] Mukhtar, Mukhtar, and Ismail Ismail. "Analisis Dampak Technostress terhadap Pembelajaran Praktikum Komputer." Jurnal JTIK (Jurnal Teknologi Informasi dan Komunikasi) 3.2 (2019): 75-78.

[8] Iqbal, Taufiq, Daniel Aprizal, and Muhammad Wali. "Aplikasi Manajemen Persediaan Barang Berbasis Economic Order Quantity (EOQ)." Jurnal JTIK (Jurnal Teknologi Informasi dan Komunikasi) 1.1 (2017): 48-60.

[9] Wali, Muhammad. "Application Optimizing the Placement of Safety Stocks Using the Max-Min Method for Printing Companies." International Journal of Research and Review 6.2 (2019): 203-210.

[10] Agustin, Yoga Handoko, and Hendra Kurniawan. "Sistem Pendukung Keputusan Penilaian Kinerja Dosen Menggunakan Metode Weighted Product (Studi Kasus: Stmik Pontianak)." Seminar Nasional Informatika (SNIf). Vol. 1. No. 1. 2017.

[11] Hardita, Veny, et al. "Perencanaan Basis Data pada Sistem Reservasi Hotel Tickle Yogyakarta." Proceeding Seminar Nasional Sistem Informasi dan Teknologi Informasi. Vol. 1. No. 1. 2018.

[12] Anisya, Anisya, and Yunita Wandyra. "Rekayasa Perangkat Lunak Pengendalian Inventori Menggunakan Metode SMA (Single Moving Average) Berbasis AJAX (Asynchronous Javascript and XML)(Studi Kasus: PTP Nusantara VI (Persero) Unit Usaha Kayu Aro)." Jurnal TeknoIf 4.2 (2016).

[13] Wali, M. "Modul Praktikum Rekayasa Perangkat Lunak." (2020).

[14] Junaidi, Agus, and Candra Sumirat. "Aplikasi Persediaan Barang PT. CAD Solusindo Menggunakan Metode Waterfall." Jurnal Sisfokom (Sistem Informasi dan Komputer) 7.1 (2018): 28-37.

[15] Frontoni, Emanuele, et al. "Optimal stock control and procurement by reusing of obsolescences in manufacturing." Computers \& Industrial Engineering 148 (2020): 106697.

[16] Faizullin, Rinat Vasilovich, and Olga Mihailovna Perminova. "MODEL OF STOCK CONTROL AT SCRAP PROCESSING ENTERPRISES." Acta Logistica 7.1 (2020): 61-64.

[17] Yürekli, Lütfiye Büşra, İsmet Kandilli, and Melih Kuncan. "Food stock control." (2020). 